\title{
Czy Polacy są za uniwersalizmem świadczeń - badanie społeczności lokalnej po wprowadzeniu Programu „Rodzina 500 Plus”. Raport z badań - region koniński
}

\begin{abstract}
Streszczenie: Od 2016 roku realizowany jest w Polsce program „Rodzina 500 Plus”, stanowiący istotny element polityki rodzinnej. W artykule przedstawiono wyniki badania, dotyczącego stosunku wyodrębnionej grupy mieszkańców do programu oraz stopnia poparcia dla jego uniwersalnego charakteru, na poszczególnych etapach realizacji. Pierwsze badanie nastąpiło po prawie roku funkcjonowania programu. Jego celem była wstępna ocena dotycząca realnego odbioru przez społeczeństwo pierwszych miesięcy realizacji Programu 500+, zarówno z punktu widzenia beneficjentów, jak i obserwatorów. Badanie z roku 2017 pozwoliło na szczegółową analizę, ocenę z punktu widzenia uniwersalnego charakteru świadczeń, stopnia akceptacji programu oraz postulowanych zmian. Studia zostały przeprowadzone metodą wywiadów bezpośrednich. We wszystkich badanych grupach widoczny jest brak zrozumienia i akceptacji uniwersalnego charakteru świadczenia. Badania z roku 2017 ukazują krytyczne wnioski wszystkich grup do uniwersalnych rozwiązań o charakterze pieniężnym, mankamenty tej formy są widoczne na konkretnych przykładach.
\end{abstract}

Slowa kluczowe: Polityka rodzinna, świadczenia uniwersalne, bezpieczeństwo społeczne, Program $500+$

\section{Wstęp}

$\mathbf{P}$ olityka rodzinna w Polsce stała się po roku 2015 istotnym elementem, realizowanego przez ugrupowanie rządzące (Obóz Zjednoczonej Prawicy), programu politycznego. Symbolem i najbardziej odczuwalnym przez społeczeństwo efektem realizacji tej polityki jest wprowadzony w 2016 roku program „Rodzina 500 Plus”. Wzbudzał on i wzbudza wiele obaw oraz kontrowersji związanych z jego uniwersalnym charakterem,

${ }^{1}$ Program „Rodzina 500+” funkcjonuje na mocy ustawy z dnia 11 lutego 2016 roku o pomocy państwa w wychowaniu dzieci (Dz. U. 2016 poz. 195). Faktycznie wszedł on w życie 1 kwietnia 2016 roku i przyczynił się do znacznej poprawy sytuacji materialnej rodzin w Polsce. W ramach programu rodzinom z dziećmi na utrzymaniu przysługiwało świadczenie wychowawcze w wysokości 500 zł na dziecko w wieku do ukończenia 18 roku życia. Zamysłem ustawodawcy jest objęcie świadczeniem 500+ jak najszerszego kręgu osób mających na swoim utrzymaniu dzieci, a przez to udzielenie wsparcia ekonomicznego rodzinom, w szczególności tym zagrożonym ubóstwem, oraz częściowe pokrycie wydatków związanych z wychowaniem i wykształceniem dzieci. W związku z tym świadczenie wychowawcze przysługuje matce, ojcu, opiekunowi prawnemu dziecka lub opiekunowi faktycznemu dziecka (art. 4 ust. 2). Początkowo było to świadczenie na 2 oraz kolejne dziecko. Zgodnie ze zmianami wprowadzonymi w Programie „Rodzina 500+”, od 1 lipca 2019 roku świadczenie wychowawcze przysługuje na każde dziecko do ukończenia 18. roku życia, bez względu na dochód osiągany przez rodzinę. 
a także możliwościami jego realizacji z uwagi na koszty i zdolności budżetu państwa w tym zakresie (Franilczyk, 2018, s. 68-75; Gajewicz, 2018, s. 76-87).

Przedmiotem przedstawionego w artykule badania jest stosunek mieszkańców Wielkopolski - byłego województwa konińskiego, do Programu w pierwszym okresie realizacji. Przeprowadzono je w latach 2016 i 2017. Badanie zostało przeprowadzone metodą wywiadu bezpośredniego i posłużyło do wyciągnięcia wniosków, dotyczących akceptacji programu oraz jego oceny po prawie 2-letnim okresie realizacji. Grupa badana - mieszkańcy byłego województwa konińskiego, mogą być reprezentantem głównych beneficjentów programu, za jakich uchodzą mieszkańcy mniejszych miast, miasteczek oraz społeczność wiejska.

Badania dotyczące program „Rodzina 500 Plus” oraz ich wyniki w kontekście zmniejszenia ubóstwa oraz wpływy na sytuację kobiet prowadzili Dziwosz (2017, s. 209-216); Gasz (2018, s. 88-101); Politaj (2018, s. 248-257); Radzik (2018, s. 59-72). Badania przeprowadzone przez CBOS bazowały na grupach liczących około 1000 osób, wyniki badań przedstawionych poniżej dotyczą grupy ponad 500-osobowej, są zatem reprezentatywne, nie tylko w skali byłego województwa konińskiego. Dotyczą one działań państwa wobec rodziny, nie zawsze oceniane przez polskie społeczeństwo pozytywnie.

\section{Metodologia oraz charakterystyka badanej spoleczności}

Badaniem objęto mieszkańców byłego województwa konińskiego, funkcjonującego w latach 1975-1998, w skład, którego wchodziło przed reformą administracyjną 18 miast i 48 gmin.

Obserwacja debaty publicznej w okresie poprzedzającym wybory prezydenckie oraz parlamentarne roku 2015, przekonały prowadzącego badanie do konieczności weryfikacji poglądów mieszkańców do bezpieczeństwa społecznego, jako jednej z kategorii powtarzających się w wystąpieniach polityków w tym okresie.

Zakładając długofalowy charakter badań, chęć oceny stosunku społeczeństwa wielkopolski do proponowanych, a następnie realizowanych reform społecznych w tym ich głównego przedsięwzięcia, programu Rodzina 500 Plus. Założono, iż główny problem badawczy związany jest z zasadnością jego wprowadzenia oraz stosunkiem do powszechnego (uniwersalnego charakteru). Na poszczególnych, podyktowanych ramami czasowymi etapach, wymagało to odpowiedzi na trzy podstawowe, równorzędne pytania:

1. Czy program w fazie jego wstępnej konceptualizacji jest akceptowany i traktowany, jako realny, możliwy do realizacji?

2. Jaki jest jego początkowy odbiór społeczny i czy jego uniwersalny charakter jest akceptowany?

3. Czy jego realizacja, ocena z perspektywy pełnego, ponad rocznego cyklu funkcjonowania, rodzi postulaty, wnioski dotyczące ewentualnych zmian?

Badania zostały przeprowadzone metodą wywiadu bezpośredniego. Podstawową, zastosowaną w badaniach techniką badawczą, służącą gromadzeniu informacji, była ankieta z wykorzystaniem kwestionariusza ankiety, liczącego w każdym cyklu badań inną ilość pytań. Kwestionariusz ankiety zawierał każdorazowo trzy zasadnicze elementy: 
1) pytania socjodemograficzne (metryczkowe);

2) pytania merytoryczne w obszarze bezpieczeństwa;

3) pytania merytoryczne o charakterze szczegółowym (zamknięte oraz otwarte).

Uwzględniając charakter i przebieg debaty w grupie pytań zadawanych respondentom, umieszczono zagadnienia dotyczące ogólnego bezpieczeństwa jednostki oraz rodziny, a także wyodrębnienia kategorii bezpieczeństwo społeczne spośród innych. W roku 2016, po kilkumiesięcznym funkcjonowaniu programu „Rodzina 500 plus”, zadano pytania związane z ogólnym pojmowaniem bezpieczeństwa - mając na uwadze, iż bezpieczeństwo społeczne ma wymiar jednostkowy oraz zbiorowy. Rozszerzono je o bardziej szczegółowe zagadnienia związane z programem: Czy czuje się Pani/Pan bardziej bezpieczny w związku z realizacją społecznych programów rządu - rodzina $500+$, leki dla seniorów? Jeśli tak, to czy ma to związek z faktem, iż dotyczy to Pani/ Pana osobiście? Istotne było pytanie dotyczące ich uniwersalnego charakteru: Czy Pani/ Pana zdaniem programy społeczne powinny być kierowane do wszystkich, czy tylko do najbiedniejszych? Badanie zostało przeprowadzone na grupie liczącej 540 osób, z podziałem na płeć ( 248 mężczyzn i 292 kobiety).

Po wprowadzeniu programu „Rodzina 500+” i traktowaniu go przez koalicję rządzącą jako główne przedsięwzięcie, stanowiące o poparciu programu wyborczego; zdecydowano się na zadanie większej ilości pytań, nastawionych bezpośrednio na jego realizację. Bardzo istotnym w przyjętym założeniu badawczym był fakt, iż pod koniec 2017 roku program funkcjonował już od ponad roku. Można było wyjść z założenia, iż znaczna część respondentów mogła występować w roli beneficjatów programu lub ich bezpośrednich obserwatorów. Obok pytań związanych z celowością i uniwersalnym charakterem, mogły pojawić się te, które dotyczyły sposobów rozdysponowania środków oraz wpływu na decyzje o charakterze rodzinnym. Tego typu argumenty, związane $\mathrm{z}$ wpływem programu na wzrost dzietności, były wielokrotnie stosowane $\mathrm{w}$ debacie publicznej. Badanie zostało przeprowadzone na grupie liczącej 646 osób, z podziałem na płeć (290 mężczyzn i 356 kobiety).

\section{Rok 2016 - praktyczna weryfikacja realizacji obietnic społecznych reform po kilku miesiącach ich funkcjonowania}

Badanie z roku 2016 przeprowadzone zostało na terenie byłego województwo konińskiego. W badaniu wzięło udział 540 osób, z podziałem na płeć (248 mężczyzn i 292 kobiety), przy nieco większej liczbie kobiet - nieznacznie większa liczba kobiet w populacji jest charakterystyczna dla społeczeństwa polskiego. Widoczne to jest na zestawieniu poniżej.

Tabela 1

Ilość osób biorących udział w badaniu - 2016

\begin{tabular}{||l|c|c|}
\hline \multicolumn{1}{|c|}{ Pleć } & Liczba & Procent \\
\hline Kobieta & 292 & 54,0 \\
\hline Mężczyzna & 248 & 46,0 \\
\hline (N) & 540 & 100,0 \\
\hline
\end{tabular}

Źródło: Opracowanie własne. 
Uwzględniając wiek uczestników dominowały osoby w przedziałach wiekowych, w których perspektywa uczestniczenia w programie obecnie lub w najbliższym czasie mogła oddziaływać na ich postrzeganie programu. Widać to na zestawieniach poniżej.

Tabela 2

Wiek uczestników badania - 2016

\begin{tabular}{||l|c|c|}
\hline \multicolumn{1}{|c|}{ Wiek } & Liczba & Procent \\
\hline Osoby do 20 roku życia & 112 & 21,0 \\
\hline Osoby w wieku 20-30 & 127 & 24,0 \\
\hline Osoby w wieku 31-45 & 135 & 25,0 \\
\hline Osoby w wieku 46-65 & 115 & 21,0 \\
\hline Osoby w wieku powyżej 65 & 51 & 9,0 \\
\hline (N) & 540 & 100,0 \\
\hline
\end{tabular}

Źródło: Opracowanie własne.

Jeżeli chodzi o miejsce zamieszkania, to dominowali w nim mieszkańcy wsi, małych miasteczek, największym ośrodkiem miejskim był Konin. Obrazują to zestawienia poniżej.

Tabela 3

Miejsce zamieszkania uczestników badania - 2016

\begin{tabular}{||l|c|c||}
\hline \multicolumn{1}{|c|}{ Miejsce zamieszkania } & Liczba & Procent \\
\hline Wieś & 266 & 49,00 \\
\hline Miasto do 2 tys. & 45 & 8,00 \\
\hline Miasto powyżej 2 tys. & 86 & 16,00 \\
\hline Miasto powyżej 50 tys. & 142 & 26,00 \\
\hline (N) & 540 & 100,00 \\
\hline
\end{tabular}

Źródło: Opracowanie własne.

Wszystkim zadano pytania dotyczące pojmowania bezpieczeństwa. Minęły emocje związane z kampanią wyborczą 2015 roku, można było założyć, iż dominować będą priorytety bezpieczeństwa indywidualnego oraz rodzinnego. Uzyskane wyniki przedstawiają zestawienia poniżej.

Tabela 4

Rozumienie bezpieczeństwa w \%

\begin{tabular}{||l|c|c|}
\hline \multicolumn{1}{|c|}{ Rozumienie bezpieczeństwa } & Liczba & Procenty \\
\hline Bezpieczeństwo osobiste & 111 & 22,0 \\
\hline Bezpieczeństwo rodzinne & 133 & 27,0 \\
\hline Bezpieczeństwo społeczności lokalnej & 55 & 11,0 \\
\hline Bezpieczeństwo społeczeństwa/państwa & 201 & 40,0 \\
\hline$(\mathrm{N})$ & 500 & 100,0 \\
\hline
\end{tabular}

Źródło: Opracowanie własne. 
W badaniu jedną kategorię wybrało 500 osób. 18 osób uznało wszystkie kategorie, jako swoje priorytety, rodzinne oraz osobiste wybrały dwie osoby, rodzinne oraz państwa 9 osób. Jak widać powyżej nadal dominował pogląd, iż najważniejszą kategorią bezpieczeństwa jest bezpieczeństwo społeczeństwa/państwa. Bezpieczeństwo rodziny oraz osobiste były, podobnie jak w poprzednim roku, na odpowiednio drugim i trzecim miejscu. $Z$ badania wynika, iż teza o przesunięciu priorytetów na sprawy osobiste oraz rodzinne nie sprawdziła się, obie te kategorie są priorytetem dla mniej niż połowy badanych $-47 \%$. Można wysunąć wnioski, iż argumenty wyborcze - kampania mówiąca o zagrożeniach o charakterze ogólnym - nadal pozostawały w umysłach respondentów.

Po uzyskaniu danych dotyczących ważności bezpieczeństwa i jego rozumienia, należało przejść do badań dotyczących programu „Rodzina 500 Plus”. Funkcjonował on od kilku miesięcy, uczestnicy mogli obserwować jego zasięg oraz sami mogli być potencjalnymi beneficjentami. Nie były to już tylko postulaty, argumentacja przeciwników i zwolenników politycznych konfrontowała się z realną rzeczywistością. Tym razem istotne są trzy pytania, które pojawiły się w badaniach:

1. Czy czuje się Pani/Pan bardziej bezpiecznie w związku ze społecznymi działaniami $-500+$; leki dla seniorów; ulgi podatkowe itp.?

2. Jeśli tak, to czy ma to związek z faktem, iż dotyczy to Pani/Pana osobiście?

3. Czy programy społeczne powinny być kierowane do wszystkich czy tylko dla najbiedniejszych?

Tym razem przyjęto hipotezę, iż pojawienie się programu w formie skonkretyzowanej ustawy oraz wypłacanie świadczeń, wpłynie pozytywnie na poczucie bezpieczeństwa obywateli. Założono również, iż większość badanych będzie za uniwersalnym charakterem świadczenia. Mogło to mieć związek z faktem, iż sami respondenci byli beneficjatami lub obserwowali ich, byli to głównie mieszkańcy wsi oraz małych miasteczek. Nie bez znaczenia był fakt, iż po wygranych przez PiS wyborach pojawiły się wśród polityków opozycji głosy, iż program powinien być rozszerzony, również na pierwsze dziecko. Byłby wtedy jeszcze bardziej uniwersalny niż w wersji realizowanej. Wyniki badań, weryfikację tej hipotezy przedstawiają dane poniżej.

Tabela 5

Poczucie bezpieczeństwa po wprowadzeniu programu „Rodzina 500 Plus"

\begin{tabular}{||l|c|c|c|c|}
\hline \multirow{2}{*}{\multicolumn{1}{|c|}{ Pleć }} & \multicolumn{2}{c|}{ Liczba } & \multicolumn{2}{c|}{ Procenty } \\
\cline { 2 - 5 } & tak & nie & tak & nie \\
\hline Kobiety & 136 & 156 & 25,0 & 29,0 \\
\hline Mężczyźni & 101 & 147 & 19,0 & 27,0 \\
\hline (N) & \multicolumn{2}{|c|}{540} & \multicolumn{2}{c|}{100,0} \\
\hline \multirow{2}{*}{ Miejsce zamieszkania } & \multicolumn{2}{|c|}{ Liczba } & \multicolumn{2}{c|}{ Procenty } \\
\cline { 2 - 5 } & tak & nie & tak & nie \\
\hline Wieś & 125 & 141 & 23,0 & 26,0 \\
\hline Miasta & 112 & 162 & 21,0 & 30,0 \\
\hline (N) & \multicolumn{3}{|c|}{540} & \multicolumn{2}{c|}{100,0} \\
\hline
\end{tabular}

Źródło: Opracowanie własne. 
Jak widać na podstawie danych, zarówno w odniesieniu do kobiet, jak i mężczyzn oraz w takim samym stopniu mieszkańców wsi oraz miast, nie sprawdziła się hipoteza, iż funkcjonowanie reformy wpłynie zdecydowanie na poczucie bezpieczeństwa. Najprawdopodobniej mogło to być wynikiem kontynuacji obaw związanych z finansowymi możliwościami realizacji programu „Rodzina 500 Plus”. Był to początek rządów Zjednoczonej Prawicy z PiS na czele.

Jeżeli chodzi o fakt bycia beneficjentem, to związek swojej pozytywnej oceny programu potwierdziło 110 badanych. Podczas gdy ogólnie pozytywny efekt, jego wpływ na poczucie bezpieczeństwa potwierdziło 237 osób. Można uznać, iż jest to wyraz pozytywnego odbioru programu, nie tylko przez samych beneficjentów.

Jak już wstępnie wskazano, że bardzo istotnym było pytanie dotyczące uniwersalnego charakteru świadczenia i kierowanie go do wybranej grupy obywateli (najbiedniejszych) lub wszystkich. Z możliwością opowiedzenia się całkowicie przeciwko jego wprowadzeniu - stosowaniu, jak widać na podstawie wyników badań przedstawionych poniżej.

Tabela 6

Stosunek badanych do uniwersalnego charakteru świadczenia - ogółem, płeć, miejsce zamieszkania

\begin{tabular}{|l|c|r|r|r|r|r|}
\hline \multirow{2}{*}{} & \multicolumn{2}{|c|}{ Tak - najbiedniejsi } & \multicolumn{2}{c|}{ Tak - wszyscy } & \multicolumn{2}{c|}{ Do nikogo } \\
\cline { 2 - 7 } & liczby & $\mathbf{\%}$ & liczby & $\mathbf{\%}$ & liczby & \multicolumn{1}{c|}{$\%$} \\
\hline Ogółem & 229 & 42,0 & 203 & 38,0 & 108 & 20,0 \\
\hline (N) & 540 & 100,0 & 540 & 100,0 & 540 & 100,0 \\
\hline Kobiety & 126 & 43,0 & 111 & 38,0 & 55 & 19,0 \\
\hline (N) & 292 & 100,0 & 292 & 100,0 & 292 & 100,0 \\
\hline Mężczyźni & 103 & 42,0 & 91 & 37,0 & 54 & 22,0 \\
\hline$(\mathrm{N})$ & 248 & 100,0 & 248 & 100,0 & 248 & 100,0 \\
\hline Wieś & 130 & 49,0 & 93 & 35,0 & 43 & 16,0 \\
\hline (N) & 266 & 100,0 & 266 & 100,0 & 266 & 100,0 \\
\hline Miasto & 99 & 36,0 & 110 & 40,0 & 65 & 24,0 \\
\hline$(\mathrm{N})$ & 274 & 100,0 & 274 & 100,0 & 274 & 100,0 \\
\hline \hline
\end{tabular}

Źródło: Opracowanie własne.

Uczestnicy badania są w przeważającej większości pozytywnie nastawieni do realizowanego programu „Rodzina 500 Plus”. Jedynie 20\% ogółu badanych było przeciwko kierowaniu programów społecznych do kogokolwiek. Taki pogląd wyraża 19\% badanych kobiet oraz $22 \%$ mężczyzn. Nieco wyższy, negatywny stosunek do świadczeń mają mieszkańcy miast $24 \%$ niż wsi $16 \%$. Jednak trzeba mieć na uwadze, iż znaczny odsetek mieszkańców miast, biorących udział w badaniu, funkcjonuje w małych miastach do 50 tys. mieszkańców. Możemy, zatem mówić o środowisku wiejsko-miejskim. Przeważa opinia, iż świadczenia powinny być kierowane jedynie do najbiedniejszych $-42 \%$. Przeważa ona znacznie nad opinią na temat uniwersalnego charakteru świadczeń o 4\%.

Opinię, iż świadczenia powinny mieć charakter uniwersalny przeważją jedynie wsród mieszkańców miast $-40 \%$. W tym wypadku przeważają o $4 \%$ poglądy, iż powinny być 
one kierowane tylko do najbiedniejszych. Opinia, iż świadczenia powinny trafiać jedynie do najbiedniejszych jest wyrażana przez większość kobiet - 43\%, a także mężczyzn. Co ciekawe największymi przeciwnikami uniwersalnego charakteru są mieszkańcy wsi. W ich przypadku, aż $49 \%$ badanych uważa, że świadczenia powinny być kierowane jedynie do najbiedniejszych.

Odnosząc się do hipotezy założonej w badaniu z roku 2016 potwierdono, iż pozytywny stosunek do świadczeń nie ma bezpośredniego związku z faktem bycia beneficjentem. Świadczenia nie zwiększyły też ogólnego poziomu bezpieczeństwa, ocenianego z perspektywy osób biorących udział w badaniu. Przeważająca wiekszość badanych jest za funkcjonowaniem świadczeń, natomiast nie potwierdziła się hipoteza związana z ich uniwersalnym charakterem. Ten stosunek, zwłaszcza widoczny wsród mieszkańców wsi, co może mieć związek z bezpośrednią obserwacją beneficjetów oraz ich potrzeb, zrodził rekomendacje dla badań przeprowadzonych w roku 2017.

Zdecydowano, iż przy badaniu tym należy zwiekszyć ilość pytań dotyczących działania samego programu „Rodzina 500 Plus” oraz jego wpływu na funkcjonowanie beneficjentów, a także ocenę form i sposobów wydatkowania środków.

\section{Rok 2017 - refleksje społeczne po ponad rocznym okresie funkcjonowania programu „Rodzina 500 Plus”}

Badanie roku 2017 zostało przeprowadzone po ponad rocznym okresie funkcjonowania programu „Rodzina 500 Plus”, przy jednoznacznym medialnym traktowaniu go jako sukcesu rządzącej koalicji i Prezydenta RP, a także braku jednoznacznej krytyki ze strony opozycji. Społeczeństwo było od ponad roku czynnym beneficjentem lub biernym obserwatorem jego funkcjonowania. W badaniu postanowiono wykorzystać zalecenia z poprzedniego roku, było to głównie związane z chęcią zweryfikowania negatywnego stosunku do rozwiązań uniwersalnych.

Badanie zostało również przeprowadzone na terenie byłego województwa konińskiego. Wzięło w nim udział 646 osób, było to 356 kobiet oraz 290 mężczyzn. Jeżeli chodzi o proporcje dotyczące poszczególnych grup wiekowych, to były one podobne jak poprzednio. Dominowały osoby mogące postrzegać rozwiązania społeczne z perspektywy bycia realnym lub potencjalnym beneficjentem. Obrazuje to zestawienie poniżej.

Tabela 7

Uczestnicy badania w poszczególnych grupach wiekowych w procentach

\begin{tabular}{|l|c|c|}
\hline \multicolumn{1}{|c|}{ Wiek } & Liczba & Procent \\
\hline Osoby do 20 roku życia & 116 & 18,0 \\
\hline Osoby w wieku 20-30 & 181 & 28,0 \\
\hline Osoby w wieku 31-45 & 176 & 27,0 \\
\hline Osoby w wieku 46-65 & 127 & 20,0 \\
\hline Osoby w wieku powyżej 65 & 46 & 7,0 \\
\hline (N) & 646 & 100,0 \\
\hline
\end{tabular}

Źródło: Opracowanie własne. 
Uczestnictwo terytorialne również nie uległo zmianie. Widoczne to jest na zestawieniu poniżej.

Uczestnicy badania według miejsca zamieszkania

\begin{tabular}{|l|c|c|}
\hline \multicolumn{1}{|c|}{ Miejsce zamieszkania } & Liczba & Procent \\
\hline Wieś & 331 & 51,0 \\
\hline Miasto do 2 tys. & 33 & 5,0 \\
\hline Miasto powyżej 2 tys. & 94 & 15,0 \\
\hline Miasto powyżej 50 tys. & 188 & 29,0 \\
\hline (N) & 646 & 100,0 \\
\hline
\end{tabular}

Źródło: Opracowanie własne.

Istotna była weryfikacja obserwacji z badań roku 2016 - wskazująca, iż potrzeby bezpieczeństwa indywidualnego nie dominują wśród respondentów. Podobnie jak w poprzednim roku, zadano pytania dotyczące wyboru kategorii mającej związek z pojęciem bezpieczeństwa. Widać to poniżej.

Tabela 9

Rozumienie bezpieczeństwa jako jednej z wybranych kategorii

\begin{tabular}{||l|c|c||}
\hline \multicolumn{1}{|c|}{ Rozumienie bezpieczeństwa } & Liczba & Procenty \\
\hline Bezpieczeństwo osobiste & 188 & 29,0 \\
\hline Bezpieczeństwo rodzinne & 286 & 44,0 \\
\hline Bezpieczeństwo społeczności lokalnej & 33 & 5,0 \\
\hline Bezpieczeństwo społeczeństwa/państwa & 139 & 22,0 \\
\hline (N) & 646 & 100,0 \\
\hline
\end{tabular}

Źródło: Opracowanie własne.

Odnosząc się w badaniu bezpośrednio do społecznych programów realizowanych przez państwo, zwrócono uwagę, zgodnie z rekomendacjami z roku 2016 na:

1) bezpośredni odbiór/ocenę polityki państwa wobec rodziny;

2) oceny wprowadzenia programu „Rodzina 500 Plus”;

3) czy badani osobiście popierają program „Rodzina 500 Plus”;

4) czy w ocenie badanych świadczenie powinno być uniwersalne i przysługiwać na każde dziecko;

5) czy świadczenie powinno być uzależnione od dochodów rodziny;

6) czy świadczenie powinno mieć zróżnicowane formy;

7) czy program „Rodzina 500 Plus” poprawił sytuację ubogich rodzin;

8) czy program „Rodzina 500 Plus” ma wpływ na dzietność w Polsce;

9) czy program „Rodzina 500 Plus” jest w Polsce nadużywany.

Przyjęto w tym przypadku hipotezę, iż społeczeństwo w wyniku dłuższego okresu uczestniczenia (bycia beneficjentem) lub bezpośrednią obserwację funkcjonowania systemu, ma praktyczne wnioski w odniesieniu do program „Rodzina 500 Plus”. Mogą one dotyczyć samego charakteru świadczeń oraz oceny z perspektywy wzrostu dzietności, a także jego nadużywania. 
Udało się zauważyć, iż zarówno ogólna ocena, jak i odbiór programu „Rodzina 500 Plus" są u większości badanych pozytywne. Chociaż ocena dobra i bardzo dobra to nadal poniżej 50\% (bardzo dobrze 11\% i dobrze 29\%). Ilustrują to wyniki badań poniżej:

Ocena polityki państwa wobec rodziny

\begin{tabular}{|l|c|c|}
\hline & Liczba & Procenty \\
\hline Bardzo dobrze & 74 & 11,0 \\
\hline Dobrze & 190 & 29,0 \\
\hline Dostatecznie & 143 & 22,0 \\
\hline Niedostatecznie & 77 & 12,0 \\
\hline Trudno powiedzieć & 162 & 25,0 \\
\hline $\mathrm{N})$ & 646 & 100,0 \\
\hline
\end{tabular}

Źródło: Opracowanie własne.

Ponieważ było to pytanie dotyczące polityki całościowej państwa wobec rodziny, tym bardziej interesujące było poznanie stosunku respondentów do program „Rodzina 500 Plus", zarówno w sensie ogólnym (posunięcie rządu), jak i osobistej oceny. Przedstawione poniżej wyniki badań wskazują, iż sam program cieszy się o wiele wyższym poparciem niż polityka państwa w stosunku do rodziny w całości.

Tabela 11

Ocena programu „Rodzina 500 Plus” jako dobrego działania Rządu

\begin{tabular}{||l|c|c|}
\hline Czy jest to dobre dzialanie ze strony Rządu? & Liczba & Procent \\
\hline Tak & 299 & 46,0 \\
\hline Raczej tak & 170 & 26,0 \\
\hline Nie & 101 & 16,0 \\
\hline Nie mam zdania & 76 & 12,0 \\
\hline (N) & 646 & 100,0 \\
\hline
\end{tabular}

Źródło: Opracowanie własne.

Podobnie, równie wysokie osobiste poparcie do programu „Rodzina 500 Plus” deklaruje większość badanych. Jest to widoczne na zestawieniu poniżej.

Tabela 12

Osobiste poparcie dla programu „Rodzina 500 Plus”

\begin{tabular}{|l|c|c|}
\hline $\begin{array}{c}\text { Czy popiera Pani/Pan program } \\
\text { „Rodzina 500 Plus”? }\end{array}$ & Liczba & Procent \\
\hline Tak & 428 & 66,0 \\
\hline Nie & 218 & 34,0 \\
\hline $\mathrm{N})$ & 646 & 100,0 \\
\hline
\end{tabular}

Źródło: Opracowanie własne.

Ocenę uniwersalności zawarto w pytaniach dotyczących powszechności świadczenia oraz uznaniowości, uzależnienia od wysokości dochodów. Również tym razem, zdecy- 
dowana większość - mimo deklaracji, iż świadczenia programu „Rodzina 500 Plus” powinny być na każde dziecko, jest przeciwko ich uniwersalnemu charakterowi. 56\% uzależnia ich przyznawanie od wysokości dochodów w rodzinie, chociaż aż $67 \%$ badanych uważa, że powinny być na każde dziecko. Widać to w zestawieniach wyników badań poniżej.

Tabela 13

Opinia badanych na temat przyznawania świadczenia „Rodzina 500 Plus” na każde dziecko

\begin{tabular}{|l|c|c|}
\hline \multicolumn{1}{|c|}{$\begin{array}{c}\text { Opinia badanych na temat } \\
\text { zakresu świadczeń }\end{array}$} & Liczba & Procent \\
\hline Tak & 433 & 67,0 \\
\hline Nie & 97 & 15,0 \\
\hline Nie mam zdania & 116 & 18,0 \\
\hline (N) & 646 & 100,0 \\
\hline
\end{tabular}

Źródło: Opracowanie własne.

Tabela 14

Uzależnienie świadczenia „Rodzina 500 Plus” od dochodów w rodzinie

\begin{tabular}{|l|c|c|}
\hline $\begin{array}{c}\text { Uzależnienie świadczenia „Rodzina 500 Plus” } \\
\text { od dochodów w rodzinie }\end{array}$ & Liczba & Procent \\
\hline Tak & 359 & 56,0 \\
\hline Nie & 69 & 11,0 \\
\hline Nie mam zdania & 218 & 34,0 \\
\hline (N) & 646 & 100,0 \\
\hline
\end{tabular}

Źródło: Opracowanie własne.

Pozytywną oceną cieszy się program „Rodzina 500 Plus” w odniesieniu do poprawy sytuacji ubogich rodzin w Polsce.

Opinia na temat wpływu programu „Rodzina 500 Plus” na poprawę sytuacji ubogich rodzin w Polsce

\begin{tabular}{|l|c|c|}
\hline $\begin{array}{c}\text { Czy program „Rodzina 500 Plus” poprawil } \\
\text { sytuację ubogich rodzin w Polsce }\end{array}$ & Liczba & Procent \\
\hline Tak & 509 & 79,0 \\
\hline Nie & 66 & 10,0 \\
\hline Nie ma zdania & 71 & 11,0 \\
\hline N) & 646 & 100,0 \\
\hline
\end{tabular}

Źródło: Opracowanie własne.

Bardzo wielu badanych uważa, iż wprowadzenie programu „Rodzina 500 Plus” poprawiło dzietność w Polsce. Chociaż trudno ocenić, czy jest to efekt medialnego entuzjazmu ze strony rządu, czy też własnych obserwacji. Obiektywizując, jest to zbyt krótki czas, by móc mówić o trendach w tym zakresie. Jednak zestawienie wyników badań, wyraźnie świadczy o przeświadczeniu badanych w tym zakresie. 
Tabela 16

Opinia na temat wpływu programu „Rodzina 500 Plus” na dzietność w Polsce

\begin{tabular}{|l|c|c||}
\hline $\begin{array}{c}\text { Czy wprowadzenie programu „Rodzina 500 Plus” } \\
\text { poprawilo dzietność w Polsce? }\end{array}$ & Liczba & Procent \\
\hline Tak & 399 & 62,0 \\
\hline Nie & 76 & 12,0 \\
\hline Nie wiem & 171 & 26,0 \\
\hline N) & 646 & 100,0 \\
\hline
\end{tabular}

Źródło: Opracowanie własne.

Ważne, z punktu widzenia praktycznych rekomendacji, są wyniki badania dotyczące zróżnicowania charakteru świadczenia oraz jego nadużywania. Opinie dotyczące nadużywania świadczeń, a tym samym podważanie charakteru programu w jego obecnym kształcie, wyraża ponad połowa badanych. Można uznać, iż może to mieć związek z wcześniejszą opinią o konieczności przyznawania świadczenia w zależności od wysokości dochodów. Potwierdza to pośrednio tezę, iż w opinii badanych świadczenia nie powinny mieć uniwersalnego charakteru. Ocena widoczna jest na zestawieniach poniżej.

Tabela 17

Opinia badanych na temat nadużywania programu „Rodzina 500 Plus"

\begin{tabular}{|l|c|c|}
\hline \multicolumn{1}{|c|}{$\begin{array}{c}\text { Czy program „Rodzina 500 Plus” jest } \\
\text { nadużywany }\end{array}$} & Liczba & Procent \\
\hline Tak & 336 & 52,0 \\
\hline Nie & 147 & 23,0 \\
\hline Nie mam zdania & 163 & 25,0 \\
\hline N) & 646 & 100,0 \\
\hline
\end{tabular}

Źródło: Opracowanie własne.

Opinie na temat nadużywania świadczenia skłaniają do postulatów związanych z ewentualnymi zmianami, dotyczącymi pieniężnego charakteru świadczeń. Jak widać, większość badanych wypowiada się na temat zmiany charakteru programu „Rodzina 500 Plus" z wyłącznie finansowych na mieszane, lub nawet tylko świadczenia niematerialne. Najprawdopodobniej wynika to z faktu, iż mieszkańcy wsi oraz małych miejscowości niejednokrotnie obserwują, iż nie trafiają one do osób, które powinny bezpośrednio wspierać dzieci.

Tabela 18

Opinia badanych na temat formy otrzymywanego świadczenia z programu „Rodzina 500 Plus”

\begin{tabular}{|l|c|c|}
\hline $\begin{array}{c}\text { Opinia badanych na temat charakteru } \\
\text { świadczeń z programu ,Rodzina 500 Plus” }\end{array}$ & Liczba & Procent \\
\hline Forma wyłącznie pieniężna & 278 & 43,0 \\
\hline Forma mieszana (pieniężna oraz świadczenia) & 288 & 45,0 \\
\hline Wyłącznie świadczenie & 80 & 12,0 \\
\hline (N) & 646 & 100,00 \\
\hline
\end{tabular}

Źródło: Opracowanie własne. 
Widać wyraźnie, iż społeczeństwo aprobując reformy w zakresie polityki rodzinnej wprowadzone przez rząd po 2015 roku, nie jest jednak za złym wydatkowaniem środków. Można przypuszczać, iż z uwagi na ten fakt oraz utrzymujące się dysproporcje społeczne, cały czas nie ma akceptacji dla uniwersalnego charakteru świadczenia. Wymagałoby to polityki informacyjnej ze strony państwa oraz większej aktywności służb społecznych, związanych z kontrolą wydatkowania środków, mających obecnie charakter pieniężny.

\section{Zakończenie}

Materiał przedstawiony powyżej jest częściowym raportem z badań prowadzonych w latach 2016 oraz 2017. Na samym wstępie realizacji Programu. O jego roli i znaczeniu świadczą fakty, iż stał się on głównym argumentem w wyborach parlamentarnych oraz prezydenckich roku 2020.

Przedstawione badania wskazują, iż społeczeństwo wielkopolski, zamieszkujące obszar byłego województwa konińskiego, po stopniowych obawach związanych z zapowiedziami dotyczącymi wprowadzenia programu „Rodzina 500 Plus”, zaaprobowała go. Weryfikacja pytania dotyczącego uniwersalnego charakteru świadczeń wskazuje, iż większość społeczeństwa jest za jakąś formą uznaniowości. Ma to związek z traktowaniem go jako świadczenia dla ludzi ubogich, a nie jak to jest w większości państw oferujących podobne formy wsparcia - ze świadczeniem uniwersalnym, związanym z faktem posiadania i wychowywania dzieci.

Nie ulega wątpliwości, iż społeczeństwo, zwłaszcza osoby zamieszkujące w gminach wiejskich oraz wiejsko-miejskich, ma możliwość bliższej obserwacji wydatkowania środków, stąd opinie dotyczące zmiany charakteru świadczeń oraz ich nadużywania przez beneficjentów programu „Rodzina 500 Plus”. Można nawet użyć stwierdzenia, iż społeczności lokalne są w ocenie realizacji bardziej racjonalne niż osoby odpowiedzialne za jego wprowadzenie. Ich pragmatyzm wychodzi poza ramy beneficjenta czy grupy dążącej do utrzymania władzy bądź jej zdobycia dla własnych korzyści.

\section{Bibliografia}

Dziwosz E. (2017), Minusy Programu Rodzina 500+, ,Zeszyty Naukowe Politechniki Śląskiej. Seria: Organizacja i Zarządzanie" (104), s. 209-216.

Franielczy A. (2018), Program Rodzina 500+ w aspekcie wydatków publicznych, „Prace naukowe Uniwersytetu Ekonomicznego we Wrocławiu" (528), s. 68-75.

Gajewicz M. (2018), Dwa lata z programem „Rodzina 500+”-ocena oraz uwarunkowania ekonomiczne programu, „Prace naukowe Uniwersytetu Ekonomicznego we Wrocławiu” (528), s. $76-87$.

Gasz M. (2018), Rola programu Rodzina 500+ w procesie redukcji zagrożenia ubóstwem $i$ wykluczeniem społecznym $w$ Polsce, „Prace naukowe Uniwersytetu Ekonomicznego we Wrocławiu” (528)2018, s. 88-101.

Łobocki M. (2000), Metody i techniki badań pedagogicznych, Oficyna Wydawnicza Impuls, Kraków. Nowak S. (1970), Metodologia badań socjologicznych, Warszawa. 
Sołoma L. (2002), Metody i techniki badań socjologicznych. Wybrane zagadnienia, Wydawnictwo Uniwersytetu Warmińsko-Mazurskiego, Olsztyn.

Politaj A. (2018), Sytuacja kobiet na rynku pracy w dobie obowiazywania programu Rodzina 500+, „Prace naukowe Uniwersytetu Ekonomicznego we Wrocławiu” (529), s. 248-257.

Radzik P. (2018), Wpływ rządowego programu „Rodzina 500+” na współczynnik aktywności zawodowej kobiet, „Studia Ekonomiczne. Zeszyty Naukowe Uniwersytetu Ekonomicznego w Katowicach" (353), s. 59-72.

Rozporządzenie Ministra Rodziny, Pracy i Polityki Społecznej z dnia 27 lipca 2017 r. w sprawie sposobu i trybu postępowania w sprawach o przyznanie świadczenia wychowawczego oraz zakresu informacji, jakie mają być zawarte we wniosku, zaświadczeniach i oświadczeniach o ustalenie prawa do świadczenia wychowawczego, Dz. U. 2017, poz. 1465.

Ustawa z dnia 11 lutego 2016 r. o pomocy państwa w wychowaniu dzieci, Dz. U. 2016, poz. 195 z późn. $\mathrm{zm}$.

Żegnałek K. (2001), Metody i techniki badawcze stosowane w badaniach pedagogicznych, Warszawa.

\title{
Do Poles support universal benefits - research on the local community after the introduction of the "500 Plus Family" program. Research report - Konin region
}

\begin{abstract}
Summary
New solutions in the field of childecare benefits under the age 18 were introduced in Poland in 2016. This article, based on survey conducted among citiziens of wielkopolska region. The results of the research presented in this article indicate growing public confidence in the "Family 500 plus" program. The lack of acceptance for universal solutions persists all the time. A significant part of the respondents consider that benefits should be directed only to the poorest families.
\end{abstract}

Key words: family, family policy, childcare benefits, "family 500 plus" program 
